\title{
GAMBARAN PENGETAHUAN PASIEN DIABETES MELLITUS TENTANG PERAWATAN LUKA ULKUS DIABETIK DI KLINIK IKHZA MEDIKA
}

\section{DESCRIPTION OF DIABETES MELLITUS PATIENTS CONCERNING DIABETIC ULCER TREATMENT IN IKHZA MEDICAL CLINIC}

\author{
Agus Khoirul Anam ${ }^{1}$, Bayu Puguh Dwi Kurniawan ${ }^{2}$ \\ 1,2 Program Studi D3 Keperawatan Blitar, Jurusan Keperawatan, Politeknik Kesehatan \\ Kementerian Kesehatan Malang
}

\begin{abstract}
ABSTRAK
Ulkus diabetik adalah salah satu bentuk komplikasi kronik diabetes mellitus berupa luka terbuka pada permukaan kulit yang dapat disertai adanya kematian jaringan setempat. Sehingga, pasien perlu mengetahui tentang perawatan luka ulkus diabeteik tersebut untuk mempercepat proses penyembuhan luka. Tujuan penelitian yaitu untuk menggambarkan pengetahuan pasien diabetes mellitus tentang perawatan luka ulkus diabetik. Metode penelitian ini menggunakan rancangan deskriptif. Populasi dalam penelitian ini adalah pasien diabetes mellitus yang menjalani rawat luka di Klinik Ikhza Medika sebanyak 31 orang dan besar sampel yang diambil adalah total populasi. Pengumpulan data dilakukan dengan menggunakan kuesioner. Waktu pengambilan data dilakukan pada tanggal 8 April - 22 Mei 2017. Hasil penelitian menunjukan bahwa pengetahuan pasien tentang perawatan luka ulkus diabetik berkategori cukup dengan prosentase 51,6\% sebanyak 16 orang. Rekomendasi bagi Klinik Ikhza Medika diharapkan dapat dijadikan bahan masukan dalam upaya meningkatkan pengetahuan pasien diabetes mellitus tentang perawatan luka ulkus diabetic dengan cara pemberian penyuluhan atau edukasi kepada pasien ulkus diabetic pada saat melakukan perawatan luka.
\end{abstract}

Kata kunci: pengetahuan, diabetes mellitus, ulkus diabetik, perawatan luka

\section{ABSTRACT}

Diabetic ulcers are a chronic form of diabetes mellitus in the form of open sores on the skin surface that can be accompanied by local tissue death. Thus, patients need to know about the treatment of diabeteic ulcer wounds to speed up the wound healing process. The purpose of this study is to describe the knowledge of patients with diabetes mellitus concerning the diabetic ulcer treatment. This research method uses descriptive design. The population in this study were diabetic mellitus patients who underwent treatment at Ikhza Medika Clinic as many as 31 people which was total population. Data collection was carried out using a questionnaire. The data was collected on April 8 to May 22, 2017. The results of the study showed that the knowledge of patients about the treatment of diabetic ulcer injuries was categorized as sufficient with a percentage of $51.6 \%$ as many as 16 people. As recommendations, Ikhza Medika Clinic is expected to use the result as input in an effort to increase the knowledge of patients with diabetes mellitus concerning the 
BMJ. Vol 6 No 2, 2019: 136-146

ISSN : $2615-7047$

DOI: https://doi.org/10.36376/bmj.v6i2

treatment of diabetic ulcer by providing counseling or education to diabetic ulcer patients during treatment.

Keywords: knowledge, diabetes mellitus, diabetic ulcers, wound treatment

\begin{tabular}{ll}
\hline Alamat Korespondensi & $\begin{array}{l}\text { : Politeknik Kesehatan Kementerian Kesehatan Malang. } \\
\text { Jl. Besar Ijen No.77C, Oro-oro Dowo, Kec. Klojen, Kota Malang, } \\
\end{array}$ \\
Jawa Timur 65119 & : aguskhoirulanam@gmail.com \\
\hline
\end{tabular}

PENDAHULUAN

Diabetes mellitus merupakan sekelompok kelainan heterogen yang ditandai oleh kenaikan kadar glukosa dalam darah atau hiperglikemia. Glukosa secara normal bersirkulasi dalam jumlah tertentu dalam darah. Glukosa dibentuk di hati dari makanan yang dikonsumsi. Insulin, yaitu suatu hormone yang diproduksi pancreas, mengendalikan kadar glukosa dalam darah dengan mengatur produksi dan penyimpanannya. (Smeltzer \& Bare, 2001).

Berdasarkan hasil Riset Kesehatan Dasar (Riskesdas) tahun 2013, proporsi penduduk $\geq 15$ tahun dengan diabetes mellitus adalah 6,9\%. Prevalensi penderita diabetes mellitus berdasarkan wawancara mengalami peningkatan dari 1,1\% (tahun 2007) menjadi 2,1\% (tahun 2013). Prevalensi diabetes mellitus yang terdiagnosis dokter dan atau gejala, tertinggi terdapat di Sulawesi Tengah (3,7\%), Sulawesi Utara (3,6\%), dan Sulawesi Selatan (3,4\%). Menurut PERKENI, 2006 diperkirakan penduduk Indonesia yang berusia di atas 20 tahun adalah sebesar 133 juta jiwa. Dengan prevalensi diabetes mellitus pada daerah urban sebesar $14,7 \%$ dan pada daerah rural sebesar 7,2\%, maka diperkirakan pada tahun 2003 terdapat penyandang diabetes sejumlah 8,2 juta di daerah urban dan 5,5 juta di daerah rural. Selanjutnya, berdasarkan pola pertambahan penduduk diperkirakan pada tahun 2030 nanti akan 194 juta penduduk yang berusia diatas 20 tahun dan dengan asumsi prevalensi diabetes mellitus pada urban $(14,7 \%)$ dan rural $(7,2 \%)$ maka di perkirakan terdapat 12 juta penyadang diabetes mellitus di daerah urban dan 8,1 juta di daerah rural. Suatu jumlah yang sangat besar dan merupakan beban yang sangat berat untuk dapat di tangani sendiri oleh dokter spesialis/subspesialis bahkan oleh semua tenaga kesehatan yang ada. Mengingat bahwa diabetes mellitus akan memberikan dampak terhadap kualitas sumber daya manusia dan peningkatan biaya kesehatan yang cukup besar.

Salah satu komplikasi diabetes mellitus yang sering dijumpai adalah terjadinya ulkus pada kaki atau sering disebut juga kaki diabetik. Manisfestasi gangguan kaki pada penderita diabetes mellitus antara lain ulkus yang terkadang tidak disadari oleh penderita sehingga menimbulkan infeksi. Kejadian ulkus kaki mencapai sekitar $15 \%$ dari seluruh penderita diabetes mellitus. Catatan yang menyebutkan bahwa dalam perjalanan penyakit sekitar 14-24\% diantara penderita kaki diabetic tersebut memerlukan tindakan amputasi. Penyebab utama amputasi anggota gerak bawah $85 \%$ disumbangkan karena ulkus kaki diabetik, atau 10 lebih banyak dibandingkan seseorang tanpa ulkus kaki.(Pract, 2010). Komplikiasi mikro dan makroangiopati yang merupakan penanda awal kejadian komplikasi yang sering kali kurang dipahami dan kurang di analisis oleh pasien diabetes mellitus. Di lain sisi 
DOI: $\underline{\text { https://doi.org/10.36376/bmj.v6i2 }}$

progresivitas penyakit akibat diabetes mellitus ini baru dirasa setelah komplikasi yang timbul menyerang organ dan mal fungsi organ yang muncul menggagu proses homeostasis tubuh. (PERKENI, 2006). Salah satu komplikasi yang penting dari diabetes mellitus adalah masalah kaki diabetes, dimana komplikasi ini merupakan masalah yang meningkat pada kesehatan masyarakat dan merupakan penyebab utama amputasi dan kematian pada pasien diabetes militus.(Desalu et al., 2011).

Prevalensi penderita ulkus diabetik di Indonesia sebesar 15\%, angka amputasi $30 \%$, angka mortalitas $32 \%$, dan ulkus kaki diabetic merupakan sebab perawatan di rumah sakit yang terbanyak, sekitar 80\% untuk diabetes mellitus (Riyanto, 2007). Sebagian perawatan diabetes mellitus selalu terkait dengan ulkus diabetik. Angka kematian dan angka amputasi masih tinggi, masing-masing sebesar 32,5\% dan 23,5\%. Nasib penderita diabetes mellitus paska amputasi masih sangat buruk, sebanyak 14,3\% akan meninggal dalam setahun paska amputasi dan sebanyak $37 \%$ akan meninggal 3 tahun paska amputasi (Waspadji, 2007). Penderita ulkus diabetik di Indonesia memerlukan biaya yang tinggi sebesar Rp. 1,3 juta sampai Rp. 1,6 juta per bulan dan Rp. 43,5 juta per tahun untuk seorang penderita (Suyono, 2007). Luka kaki diabetik merupakan luka kronis yang harus dilakukan tindakan yang tepat, jika luka kaki tidak mendapatkan perawatan yang tepat maka akan memperparah luka dan akan mempersulit penyembuhan yang bisa berakibat amputasi. Maka dari itu tujuan perawatan luka kaki antara lain adalah untuk mengontrol infeksi, meningkatkan fungsi dan kualitas hidup, mempertahankan status kesehatan, mengurangi biaya, dan mencegah amputasi (Maryunani, 2013).

Pengetahuan pasien diabetes mellitus untuk mengontrol komplikasai ulkus kaki diabetik sangat berkontribusi untuk mencegah terjadinya ulkus diabetik. Jika pasien memiliki pengetahuan yang memadai meraka akan dapat berlatih untuk mencegah ulkus diabetic (Begum at al., 2010). Pengetahuan atau kognitif merupakan domain yang sangat penting untuk terbentuknya tindakan atu perilaku seseorang. Perilaku yang didasari oleh pengetahuan dan sikap yang positif, perilaku tersebut akan berlangsung laggeng. Pengetahuan penderita tentang diabetes mellitus merupakan sarana yang dapat membantu penderita menjalankan penanganan diabetes mellitus semasa hidupnya sehingga semakin banyak dan semakin baik penderita mengerti tentang penyakitnya semakin mengerti bagaimana harus mengubah perilakunya dan mengapa hal itu di perlukan (Notoatmodjo, 2007 \& Waspadji, 2007).

Dari hasil studi pendahuluan yang dilakukan peneliti di Klinik Ikhza Medika pada tanggal 13 Desember 2016, didapatkan dari 5 responden, dari responden tersebut dapat disimpulkan bahwa $60 \%$ memiliki tingkat pengetahuan cukup dan $40 \%$ memiliki tingkat pengetahuan kurang. Berdasarkan uraian diatas, permasalahan yang didapatkan pada pasien rawat luka ulkus diabetik adalah kurangnya pengetahuan pasien rawat luka ulkus diabetik tentang perawatan luka..

Tujuan penelitian ini adalah untuk mengetahui gambaran pengetahuan pasien diabetes mellitus tentang perawatan luka ulkus diabetik, dengan kejadian ulkus diabetikum di Klinik Ikhza Medika.

\section{METODE PENELITIAN}

Penelitian ini menggunakan jenis penelitian deskriptif. Metode deskriptif adalah metode dengan tujuan peneliti ingin mengetahui tingkat pengetahuan pasien diabetes militus tentang perawatan luka ulkus diabetik. 
Dalam penelitian ini yang menjadi populasi penelitian adalah pasien diabetes militus dengan ulkus diabetik di Klinik Ikhza Medika sebanyak 31 pasien. Peneliti menetapkan jumlah sampel yang diambil sebanyak 31 pasien diabetes militus dengan ulkus diabetik. Penelitian ini menggunakan teknik Sampling jenuh (Total sampling) yaitu teknik penentuan sampel bila semua anggota populasi digunakan sebagai sampel.

Instrumen penelitian yang digunakan adalah angket closended-multiple choice artinya kuisioner tertutup yang sudah disediakan jawabanya sehingga responden tinggal memilih dengan memberi check list $(\sqrt{ })$ pada pilihan jawaban yang tersedia.

Untuk pengukuran pengetahuan, setiap jawaban benar diberikan skor 1 dan jawaban yang salah diberikan skor 0 . Berdasarkan skoring tersebut jawaban benar dari masing-masing responden dijumlahkan dan dibandingkan dengan jumlah yang diharapkan kemudian dikalikan 100\% dan hasilnya berupa prosentase (Arikunto, 2006).

Rumusan yang digunakan adalah :

$$
n=\frac{S p}{S m} \times 100 \%
$$

Keterangan :

$\mathrm{n} \quad=$ Nilai

$\mathrm{Sp}=$ Skor perolehan

$\mathrm{Sm}=$ Skor maksimal

Dalam prosentase tersebut kemudian ditafsirkan ke dalam skala kualitatif dengan menggunakan skala yaitu :

$$
\begin{array}{ll}
\text { Baik } & \text { : jika } 76-100 \% \\
\text { Cukup } & : \text { jika } 56-75 \% \\
\text { Kurang } & : \text { : jika }<56 \%
\end{array}
$$

\section{HASIL DAN PEMBAHASAN}

\section{HASIL PENELITIAN \\ Karakteristik responden}

Penelitian dilaksanakan di di Klinik Griya Sehat Ikhza Medika yang bertempat di Jl. Raya Bence RT 01/ RW 03 Kel. Bence, Kec. Garum, Kab. Blitar. Data karakteristik responden terdiri dari karakteristik berdasarkan umur, jenis kelamin, lama menderita diabetes mellitus, pendidikan terakhir, pekerjaan, pernah mendapatkan informasi tentang penrawatan luka Ulkus Diabetik, sumber informsi, jika terdapat luka ulkus diabetic apakah anda ingin merawatnya, dan orang yang di anggap penting dalam kehidupan.

Tabel 2 Distribusi frekuensi gambaran pengetahuan pengetahuan pasien diabetes mellitus tentang perawatan luka ulkus diabetic berdasarkan parameter kueisioner

\begin{tabular}{|c|c|c|c|c|c|c|c|c|c|}
\hline \multirow{2}{*}{ No } & \multirow{2}{*}{ Kategori } & \multicolumn{7}{|c|}{ Parameter } & \multirow{2}{*}{$\%$} \\
\cline { 3 - 10 } & & C1 & C2 & C3 & C4 & C5 & C6 & & \\
\hline 1 & Baik & 1 & 2 & 1 & 1 & 2 & 1 & 8 & $44,4 \%$ \\
\hline 2 & Cukup & - & - & 1 & - & 1 & 2 & 4 & $22,2 \%$ \\
\hline 3 & Kurang & 2 & 1 & 1 & 2 & - & - & 6 & $33,3 \%$ \\
\hline \multicolumn{8}{|c|}{ Jumlah } \\
\hline
\end{tabular}

Balimedikajurnal.com 
DOI: https://doi.org/10.36376/bmj.v6i2

Hasil penelitian menunjukkan sebagian umur pasien 45\% (14 orang) adalah umur 40 - 49 tahun, sebagian besar jenis kelamin responden 68\% (21 orang) adalah laki-laki, sebagian kecil responden 35\% (11 orang) adalah menderita diabetes mellitus selama 3 tahun, sebagian responden $45 \%$ (14 orang) adalah berpendidikan SMA, sebagian besar responden $67 \%$ (21 orang) adalah bekerja sebagai swasta, sebagian besar responden $68 \%$ (21 orang) adalah pernah mendapatkan informasi tentang perawatan luka ulkus diabetik, sebagian besar responden $68 \%$ ( 21 orang) adalah mendapat informasi dari pelayanan kesehatan, seluruh responden 100\% (31 orang) adalah ingin merawat lukanya, dan sebagian responden $43 \%$ (13orang) adalah anak sebagai orang yang dianggap penting.

\section{Pengetahuan pasien Diabetes Mellitus tentang perawatan luka ulkus diabetikum}

Tabel 1 Distribusi frekuensi gambaran pengetahuan pasien Diabetes Mellitus tentang perawatan luka ulkus diabetikum

\begin{tabular}{|c|c|c|}
\hline Pengetahuan & Frekuensi & Prosentase \\
\hline Baik & 9 & $29.0 \%$ \\
\hline Cukup & 16 & $51.6 \%$ \\
\hline Kurang & 6 & $19.4 \%$ \\
\hline Total & 31 & $100 \%$ \\
\hline
\end{tabular}

Berdasarkan tabel 1 dapat disimpulkan bahwa pengetahuan Diabetes Mellitus mellitus tentang perawatan luka Ulkus Diabetikum sebanyak 29.0\% (9 orang) berkategori baik, sebanyak 51.6\% (16 orang) berkategori cukup, dan sebanyak $19.4 \%$ (6 orang) berkategori kurang

\section{Pengetahuan pasien Diabetes Mellitus tentang perawatan luka ulkus diabetikum berdasarkan parameter kueisioner}

Berdasarkan tabel 2 dapat disimpulkan dari parameter C1-C6 terdapat pernyataan dengan kategori baik sebesar $44,4 \%$ (8 pernyataan), Pernyataan dengan kategori cukup sebesar 22,2\% (4 pernyataan, dan pernyataan dengan kategori kurang sebesar $33,3 \%$ (6 pernyataan)

\section{PEMBAHASAN}

Pengetahuan (knowledge) adalah hal-hal yang kita ketahui tentang kebenarannya yang ada di sekitar kita tanpa harus menguji kebenarannya, di dapat dari pengamatan yang lebih mendalam (Wasis, 2010). Pengetahuan di bagi menjadi enam tingkatan yaitu C1-C6 (Tahu, memahami, apikasi, analisa, sintesis, dan evaluasi). Terdapat enam factor yang mempengaruhi pengetahuan yaitu pendidikan, umur, minat, pengalaman, lingkungan, dan orang yang dianggap penting.

\section{Parameter dengan kategori baik}

Dari hasil penelitian dapat diketahui bahwa dari parameter mengenal tanda infeksi (C2) dengan pernyataan ulkus diabetik adalah salah satu bentuk komplikasi menahun dari diabetes mellitus, berupa luka terbuka pada permukaan kulit, hampir 
seluruhnya responden yaitu sebanyak $96,77 \%$ (30 responden) dapat menjawab pernyataan dengan benar (kategori baik), dan pernyataan infeksi pada luka dapat terjadi jika kebersihan dan kepatuahan dalam perawatan luka kurang baik hampir seluruhnya responden yaitu $90,32 \%$ (28 responden) dapat menjawab pernyataan dengan benar (kategori baik). Selain itu parameter kemampuan dalam mencegah dan mengatasi luka memburuk (C5) dengan pernyataan perawatan luka yang rutin, kebersihan luka yang baik, dan pembalutan luka akan mencegah perluasan luka hampir seluruhnya responden yaitu 93,55\% (29 responden) dapat menjawab pernyataan dengan benar (kategori baik). dan pernyataan kepatuhan diet, dan pengobatan secara rutin diabetes dapat mencegah terjadinya perluasan luka, hampir seluruhnya responden yaitu $90,32 \%$ (28 responden) dapat menjawab pernyataan dengan benar (kategori baik). Menurut Yudhityarasati (2007) terdapat lima tanda infeksi yaitu calor (panas), dolor (nyeri), rubor (kemerahan), tumor (bengkak), funcsiolesa (perubahan fungsi). Dalam hal perawatan luka ulkus diabetic factorfaktor yang dapat memperburuk kondisi luka yaitu jika terjadi infeksi pada luka, infeksi pada luka tersebut dapat ditandai dengan adanya warna kehijauan pada luka, bengkak, terasa nyeri, dan terdapat bau pada luka, maka dari itu perawatan luka dilakukan untuk mencegah terjadinya infeksi pada luka dan mempercepat proses penyembuhan (Maryunani, 2013). Selain itu pencegahan luka meluas dapat dilakukan dengan kontrol gula darah/diet yang tepat, hal ini berguna untuk menjaga kadar gula dalam darah tetap normal supaya dapat mempercepat proses penyembuhan. Menurut pendapat peneliti dalam parameter mengenal tanda infeksi (C2) hampir seluruhnya responden menjawab benar, hal ini dikarenakan pada saat rawat luka, responden mendapatkan informasi mengenai kondisi lukanya, meliputi tanda-tanda infeksi selain itu responden juga dapat melihat atau mengobservasi bagaimana kondisi lukanya tersebut. Selanjutnya perameter kemampuan dalam mencegah dan mengatasi luka memburuk (C5), hampir seluruhnya responden juga menjawab benar, hal ini dikarenakan pada saat rawat luka pasien diberikan informasi oleh perawat tentang cara mencegah luka memburuk secara benar, contohnya menjaga kebersihan luka dan balutan, diet rendah gula, selain itu di era modern ini masyarakat dengan mudah mencari informasi dari internet.

Faktor-faktor yang mempengaruhi pengetahuan (baik) responden yaitu salah satunya adalah pendidikan. Dalam penelitian ini dari hasil tabulasi silang antara pengetahuan dengan pendidikan didapatkan hasil $12,9 \%$ atau (4 orang) berpengetahuan baik adalah pendidikan SMA. Menurut Mubarak (2007) Semakin tinggi pendidikan seseorang semakin mudah menerima informasi khususnya kesadaran dalam pemberdayaan. Sebaliknya pendidikan yang rendah akan sulit dalam menerima pemberdayaan dan pengalaman adalah suatu kejadian yang pernah dialami seseorang dalam berinteraksi dengan lingkungannya. Peneliti berpendapat bahwa dengan pendidikan yang semakin tinggi, maka proses berfikir akan lebih matang dan mudah dalam menerima informasi sehingga dapat meningkatkan pengetahuan yang lebih baik

Selanjutnya adalah factor informasi. Hasil penelitian didapatkan bahwa $67,7 \%$ (21 orang) pernah mendapatkan informasi tentang perawatan luka ulkus diabetikum. Dari hasil tabulasi silang antara pengetahuan dengan informasi, di dapat 29,0\% (9 orang) dengan pengetahuan baik. Menurut Notoatmodjo (1997), mengatakan bahwa informasi akan memberikan pengaruh pada pengetahuan. jika ia mendapat informasi yang cukup dari berbagai media seperti televise, radio, 
DOI: $\underline{\text { https://doi.org/10.36376/bmj.v6i2 }}$

internet, dan surat kabar maka hal itu akan dapat meningkatkan pengetahuan seseorang. Menurut peneliti, pada era sekarang sangat mudah untuk mendapat kan informasi kesehatan, misalkan dari media elektronik maupun media cetak. Jadi informasi kesehatan bukan hanya dari pelayanan kesehatan saja akan tetapi dapat di peroleh dari media tersebut.

\section{Parameter dengan kategori cukup}

Dari hasil penelitian dapat diketahui bahwa dari parameter mengevaluasi tentang perkembangan luka (C6) dengan pernyataan jika dilakukan perawatan luka dengan baik dan rutin maka akan terjadi perbaikan luka yang ditandai warna merah/pink pada luka, sebagian besar responden yaitu 70,97\% (22 responden) dapat menjawab pernyataan dengan benar (kategori cukup). Dan pernyataan amputasi kaki diabetik dilakukan pada luka diseluruh kaki atau sebagian tungkai bawah, kaki yang tidak dapat diselamatkan atau menghitam, sebagian besar responden yaitu 74,19\% (23 responden) dapat menjawab pernyataan dengan benar (kategori cukup). Kejadian yang sering ditakuti pada pasien-pasien ulkus diabetik adalah amputasi, amputasi dilakukan jika luka sudah menghitam dan mengeras akibat banyaknya jaringan yang mati, otomatis tindakan amputasi harus dilakukan karena jika di biarkan justru dapat membahayakan penderita, misalnya: luka akan meluas ke organ tubuh lainya dan akan menjadi tempat bersarangnya bakteri yang akan memperparah luka. Amputasi kaki diabetik dilakukan pada luka kaki derajat V, di mana terjadi gangren pada seluruh kaki atau sebagian tungkai bawah, kaki yang tidak dapat diselamatkan, dan nekrosis luas harus di amputasi (Maryunani, 2013). Untuk mencegah terjadinya amputsi kaki diabetic tersebut maka harus dilakukan perawatan luka ulkus diabetic yang baik dan benar, hal ini bertujuan untuk mencegah terjadinya infeksi dan kematian jaringan (nekrosis). Hal-hal yang harus diketahuai dalam perawatan luka adalah proses penyembuhan luka, meliputi warna dasar luka. Warna dasar luka yang baik adalah luka dengan warna dasar pink/kemerahan, sebaliknya luka yang memburuk ditandai dengan warna dasar luka kehitaman dan terdapat nanah (Maryunani, 2013). Menurut pendapat peneliti dalam parameter mengevaluasi tentang perkembangan luka (C6) sebagian besar responden menjawab cukup, hal ini dikarenakan responden dapat melihat kondisi luka nya sendiri pada saat dilakukan perawatan luka oleh perawat, disini responden dapat mengevaluasi sendiri bagaimana kondisi lukanya tersebut, meliputi warna dasar luka, bau, dan keaadaan umum luka. Selain itu responden dapat bertanya kepada perawat bagaimana kondsi luka yang baik dan tidak baik. Akan tetapi responden belum paham dengan sempurna mengenai proses penyembuhan atau perkembangan luka yang baik dan tidak baik, dikarenakan responden tidak memiliki pendidikan khusus dibidang kesehatan.

Faktor-faktor yang mempengaruhi pengetahuan (cukup) responden yaitu salah satunya adalah umur, hasil penelitian menunjukan terdapat $45,2 \%$ (14 orang), dengan prosentase umur terbanyak, yaitu umur 40-49 tahun. Hasil tabulasi silang antara umur dengan pengetahuan didapatkan hasil $35,5 \%$ atau (11 orang) berpengetahuan cukup. Abu Ahmadi (1991), mengatakan bahwa daya ingat seseorang itu salah satunya dipengaruhi oleh umur, dengan bertambahnya umur seseorang akan berpengaruh pada pertambahan pengetahuan yang diperolehnya. Menurut pendapat dari peneliti bahwa secara umum tingkat pengetahuan seseorang akan mengalami pertambahan seiring dengan bertambahan umur, dan akan 
DOI: $\underline{\text { https://doi.org/10.36376/bmj.v6i2 }}$

mencapai puncaknya pada umur-umur tertentu, jadi pada umur tersebut pemikiran atau pengetahuan sudah semakin matang.

Selanjutnya adalah pengalaman, dari hasil penelitian menunjukan bahwa lamanya menderita diabetes mellitus terbanyak adalah 3 tahun yaitu, 35,5\% atau (11 orang). Dari hasil tabulasi silang antara pengetahuan dengan lama menderita diabetes mellitus didapat 19,4\% (6 orang) dengan pengetauan cukup. Menurut Notoadmodjo (2004), pengalaman merupakan guru yang paling baik. Pengalaman merupakan sumber pengetahuan dan suatu cara untuk memperoleh kebenaran pengetahuan. Pengalaman yang dimaksut dalam penelitian ini adalah lamanya pasien menderita diabetes mellitus. Peneliti berendapat bahwa semakin lama pasien menderita diabetes mellitus, maka semakin tinggi pula tingkat pengetahuan nya tentang perawatan luka ulkus diabetes. Hal ini di karenakan adanya dukungan oleh beberapa hal, diantaranya sering terpapar informasi yang didapat melalui pelayanan kesehatan, orang lain, maupun media masa, hal ini tentu dapat meningkatkan pengetahuan pasien diabetes mellitus tentang perawatan luka ulkus diabetikum.

\section{Parameter dengan kategori kurang}

Dari hasil penelitian dapat diketahui bahwa dari parameter pengertian ulkus diabetic $(\mathrm{C} 1)$ dengan pernyataan penyebab terjadinya luka ulkus diabeteik adalah virus, sebagian kecil responden yaitu $29,03 \%$ ( 9 responden) menjawab benar (kategori kurang). Dan pernyataan tanda gejala ulkus diabetic adalah hilangnya atau berkurangnya sensasi nyeri (baal), sebagian responden yaitu 41,94\% (13 responden) menjawab benar (kategori kurang). Selanjutnya parameter memahami berapa kali luka harus dibersihkan/ganti balutan (C4) dengan pernyataan bukan merupakan tanda infeksi jika warna dasar luka berwarna kehijauan, terasa nyeri (sakit), bengkak, dan panas, sebagian responden yaitu 41,94\% (13 responden) menjawab benar (kategori kurang). Dan pernyataan setiap 3-5 hari sekali luka ulkus diabetik dilakukan perawatan luka, tergantung jenis luka dan kondisi balutan, sebagian kecil responden yaitu 32,26\% (10 responden) menjawab benar (kategori kurang). Ulkus diabetika adalah salah satu bentuk komplikasi kronik diabetes mellitus berupa luka terbuka pada permukaan kulit yang dapat disertai adanya kematian jaringan setempat (Robert, 2004). Menurut Soegondo (2009), mengatakan penyebab kaki diabetes mellitus dilatar belakangi faktor, yaitu gula darah yang tinggi, gangguan pembuluh darah, gangguan persyarafan (neuropati), dan infeksi. Tanda dan gejala ulkus diabetik adalah hilangnya atau berkurangnya sensasi nyeri (baal), adanya firusaatau kulit kering, kelainan bentuk kaki, dan sekeliling kulit terdapat selulitis. Menurut Yudhityarasati (2007) terdapat lima tanda infeksi yaitu calor (panas), dolor (nyeri), rubor (kemerahan), tumor (bengkak), funcsiolesa (perubahan fungsi). Untuk pencegahan infeksi tersebut maka dilakukan manajemen perawatan luka ulkus diabetic yaitu yang pertama penucian luka (cleansing), bertujuan untuk membuang jaringan nekrosis, cairan luka yang berlebihan, sisa balutan yang digunakan dan sisa metabolik tubuh pada permukaan luka, pengangkatan (debridement), bertujuan untuk mengangkat jaringan mati (nekrosis), dan yangterakhir adalah dressing (pembalutan), bertujuan untuk menutup luka agar melindungi luka dari kotoran luar. Dalam hal perawatan luka ini, biasnya dilakukan 3-5 hari sekali tergantung kondisi luka dan balutan. Menurut pendapat peneliti dalam parameter pengertian ulkus diabetic (C1) sebagian kecil responden menjawab benar, hal ini dikarenakan responden kurang terpapar informasi dari 
pelayanan kesehatan, kurangnya kesadaran responden dalam mencari informasi tentang ulkus diabetik. Dan parameter memahami berapa kali luka harus dibersihkan/ganti balutan (C4) sebagian kecil responden juga menjawab benar, hal ini dikarenakan responden tidak berani mengambil keputusan dan menyerahkan sepenuhnya jadwal rawat luka kepada perawat.

Faktor-faktor yang mempengaruhi pengetahuan (kurang) responden yaitu salah satunya adalah pendidikan, dari hasil tabulasi silang antara pendidikan terakhir dengan pengetahuan tentang perawatan luka sebesar 6.5\% (2 orang) memiliki pengetahuan yang kurang adalah pendidikan sekolah dasar. Menurut Mubarak (2007) Semakin tinggi pendidikan seseorang semakin mudah menerima informasi khususnya kesadaran dalam pemberdayaan. Sebaliknya pendidikan yang rendah akan sulit dalam menerima pemberdayaan dan pengalaman adalah suatu kejadian yang pernah dialami seseorang dalam berinteraksi dengan lingkungannya. Menurut peneliti memang benar dengan apa yang terdapat dengan teori, bahwa semakin tinggi pendidikan maka semakin tingi pula pengetahuan dan sebalik nya semakin rendah pendidian maka semakin rendahnya tingkat pengetahuan. Dalam penelitian ini pengetahuan yang kurang merupakan responden yang berpendidikan SD.

Selanjutnya adalah informasi, hasil penelitian didapatkan bahwa 32.3\% (10 orang) tidak pernah mendapatkan informasi tentang perawatan luka ulkus diabetikum. Dari hasil tabulasi silang antara pengetahuan dengan informasi, di dapat 6.5\% (2 orang) dengan pengetahuan kurang. Menurut Notoatmodjo (1997), mengatakan bahwa informasi akan memberikan pengaruh pada pengetahuan. jika ia mendapat informasi yang cukup dari berbagai media seperti televise, radio, internet, dan surat kabar maka hal itu akan dapat meningkatkan pengetahuan seseorang. Menurut peneliti bahwa apabila responden tidak pernah mendapatkan informasi tentang perawatan luka maka responden tersebut tidak mengetahui bagaimana cara perawatan luka yang baik dan benar, tidak bisa menilai baik buruknya perkembangan luka, dan tidak bisa mengenal tanda infeksi.

\section{A. Kesimpulan}

\section{KESIMPULAN DAN SARAN}

Berdasarkan hasil penelitian dan pembahasan yang telah dilakukan dapat ditarik kesimpulan bahwa pengetahuan pasien diabetes mellitus tentang perawatan luka ulkus diabetikum di klinik Ikhza Medika paling banyak yaitu kategori cukup yaitu sebesar 51.6\% (16 orang), kategori baik sebesar 29.0\% (9 orang), dan kategori kurang sebesar $19.4 \%$ (6 orang).

\section{B. Saran}

Sesuai dengan kesimpulan yang telah dikemukakan, peneliti ingin memberikan beberapa saran sebagai berikut:

1) Bagi Prodi D3 Keperawatan Blitar

Hasil penelitian gambaran pengetahuan pasien diabetes mellitus tentang perawatan luka ulkus diabetic di klinik Ikhza Medika ini, diharapkan dapat dijadikan sebagai gambaran untuk belajar atau untuk menambah pengetahuan khusus nya di bidang keperawatan medical bedah mengenai ulkus diabetic dan perawatannya 
DOI: https://doi.org/10.36376/bmj.v6i2

2) Bagi Klinik Ikhza Medika

Hasil penelitian ini diharapkan dapat dijadikan bahan masukan pemikiran dalam upaya meningkatkan pengetahuan pasien diabetes mellitus tentang perawatan luka ulkus diabetik. Karena hasil penelitian ini didapatkan prosentase terbesar pasien diabetes mellitus memiliki pengetahuan cukup tentang perawatan luka ulkus diabetikum. Oleh karena itu sebaiknya lebih meningkatkan lagi dalam hal pemberian informasi mengernai perawatan luka tersebut dengan cara pemberian penyuluhan atau edukasi kepada pasien ulkus diabetic pada saat melakukan perawatan luka.

3) Bagi pasien Diabetes Mellitus dengan Ulkus Diabetik

Hasil penelitian ini diharapkan pasien diabetes mellitus dengan ulkus diabetik dapat menambah pengetahuan tentang perawatan luka ulkus diabetik khususnya mengenai evaluasi perkembangan luka

4) Bagi peneliti selanjutnya

Hasil penelitian ini dapat digunakan sebagai data dasar untuk melaksanakan penelitian lebih lanjut yang berkaitan dengan perawatan luka ulkus diabetik. misalnya dengan judul upaya petugas kesehatan dalam meningkatkan pengetahuan pasien diabetes mellitus tentang perawatan luka ulukus diabetikum.

\section{DAFTAR PUSTAKA}

Ahmadi, Abu. 1991. Psikologi Sosial. Jakarta: PT. Rineka Cipta.

Arikunto, Suharsimi. 2006. Prosedur Penelitian Suatu Pendekatan Praktik. Jakarta: PT Rineka Cipta

Hidayat, A.A. 2007 Metode Penelitian Keperawatan Dan Tehnik Analisis Data.. Jakarta: Salemba Medika

.Hidayat, A.A.2009. Riset Keperawatan Dan Teknik Penulisan Ilmiah. Jakarta: Salemba Medika.

Kowalak, dkk. 2011. Buku Ajar Patofisiologi. Alih Bahasa: Andry Hartono. Jakarta: EGC.

Laporan Hasil Riset Kesehatan Dasar (RISKESDAS) Nasional 2013.

Maryunani, A. 2013. Pemgenalan Praktis Step By Step Perawatan Luka Diabetes dengan Metode Modern. Bogor: Penerbit IN MEDIA.

Misnadiarly. 2006. Diabetes Militus: Ulcer, Infeksi, Ganren. Jakarta: Popular Obor.

Mubarak, W, I., Chayantin, N., Rozikin, F., Supriadi. 2007. Promosi Kesehatan Sebuah Pengantar Proses Belajar Mengajar dalam Pendidikan. Yogyakarta: Graha Ilmu.

Notoatmodjo, S. 2003. Pendidikan dan Perilaku Kesehatan. Jakarta: Rineka Cipta.

Notoatmodjo. 2012. Metodologi Penelitian Kesehatan. Jakarta: Rineka Cipta.

Nursalam. 2003. Konsep dan penerapan Metodologi Penelitian Ilmu Keperawatan. Jakarta:Salemba Medika

Nursalam. 2008. Konsep dan Penerapan Metodologi Penelitian Ilmu Keperawatan, Edisi 2. Jakarta: Salemba Medika.

Balimedikajurnal.com 
DOI: https://doi.org/10.36376/bmj.v6i2

Nursalam. 2013. Metodologi Penelitian Ilmu Keperawatan: Pendekatan Praktis Edisi 3. Jakarta: Salemba Medika.

Pramudyo, R. 1996. Buku Ajar Ilmu Penyakit Dalam. Jilid 1. Edisi 3. Jakarta: Balai Penerbit FKUI.

Robert. 2004. Diabetes Militus: Ulcer Diabetik Foot. Jurnal Keperawatan Vol 3.

Smeltzer, S. \& Bare, B. 2001. Buku Ajar Keperawatan Medikal Bedah. Jakarta: EGC

Soegondo, S., Soewondo, P. Subekti, I. 2009. Penatalaksanaan Diabetes Terpadu. Jakarta: Balai Penerbit FKUI.

Sudoyo, dkk. 2006. Buku Ajar Ilmu Penyakit Dalam Edisi 3. Jakarta: Pusat Penerbit Departemen Penyakit Dalam FKUI.

Suradi. 2007. Management Lower Extremity Ulcer. Pontianak: RSUD Soedarso

Suyono, Slamet dkk. 2009. Penatalaksanaan Diabetes Terpadu. Jakarta: FKUI

Wasis. 2008. Pedoman Riset Praktis Untuk Profesi Perawat. Jakarta: EGC 